\title{
PERJANJIAN TERAPEUTIK SEBAGAI DASAR BAGI DOKTER DALAM MEAKUKAN PENANGANAN MEDIS
}

\section{Sabir Alwy, 1}

Afdhal. ${ }^{2}$

\begin{abstract}
This research aims to determine the relationship between doctor and patient in a therapeutic agreement, as provided for in Informend Consent and the law of medical practice for doctors and patients understand the obligations and responsibilities as well as provide insights for health professionals, especially physicians about the importance of treaties in creating therapeutic medical services appropriate to the patient.

The research was conducted at two hospitals in the city of Makassar is Wahidin Sudirohusodo Hospitals and Hospitals Grestelina. Primary data collection instruments and interview conducted with the data seknder done with literature study and data collection at two institutions. Data were analyzed qualitatively.

From the results showed that the Therapeutic relationship that occurs between doctor and patient is currently well underway with the hospital where doctors and Grestelina Wahidin Sudirohusodo been clearly understood to provide information needed by patients from both phases of history, diagnosis, so that everything is recorded in prgnosis medical records. The patient has had the ability to complain of illness, but patients have a tendency to be resigned to that advice from doctors is not done. Doctors and hospitals Wahidin Sudirohusodo Grestelina has done its responsibility in caring for patients with always do a routine for inpatients and besikap polite and respect the limits of its competence in accordance with the oath that doctors say. Patients have appreciated doter with trying to provide honest information in which the function of creating kepercaayaan between doctor and patient. Sudirohusodo Wahidin hospital doctors and medical services Grestelina have done in the form of counseling to the patient in choosing the appropriate medication and treatment conditions keuanganya quickly for emergency room patients are in accordance with the SOP (Standard Operating Procedure). SOP (Standard Operating Procedure also regulates every doctor who wants to practice in the hospital and Grestelina Wahidin Sudirohusodo must have the STR (letter of registration) and SIP (Permit Practice) through the provisions made by the Institute COUNCIL (Physician Discipline Committee) and the Organization of Ethics.
\end{abstract}

\footnotetext{
1 Dosen Universitas Hasanuddin Makassar dan Wakil Ketua MKDKI Konsil Kedokteran Indonesia (2005-2015)

2 Dosen Universitas Borneo Tarakan dan Pengajar Hukum Kesehatan UBT, afdhalmr1@gmail.com
} 


\section{Pendahuluan}

Hukum adalah sarana untuk menciptakankeserasian antara hubungan dokter dan pasien guna menunjang keberhasilan pelayanan medis. Pembangunan jangka Panjang bidang kesehatan, yang merupakan bagian dari Sistem , diarahkan untuk mencapai tujuan utama sektor kesehatan.

Hubungan hukum antara dokter dan pasien saat ini dikenal sebagai suatu transaksi medis yang disebut terapeutik yakni pasien dan dokter saling mengikatkan dirinya melalui kata sepakat dalam melaksanakan pengobatan bagi pasien. Pada pelaksanaan perjanjian terapeutik antara dokter dan pasien, dokter tidak menjanjikan kesembuhan pasien, tetapi yang dilakukan oleh dokter adalah berupaya secara maksimal untuk menyembuhkan pasien sesuai dengan kompetensi yang dilmilikinya.

Dahulu dokter dianggap tahu segalanya,dan dalam pandangan sehari-hari seorang pasien senantiasa menjalankan suatu peran yang sangat lemah, pasif, dan sangat tergantung kepada pihak lain akibat sakit yang dideritanya. Selain itu pasien juga dianggap tidak mempunyai pengetahuan yang cukup tentang kesehatandan penyakit yang dideritanya. Hubungan yang sederajat merupakan titik pangkal dari hubungan perjanjian yang meghendaki adanya kesepakatan antara para pihak yang saling memberikan prestasi atau jasa. Masing- masing pihak dianggap mempunyai pengetahuan yang sama tentang penyakit dan cara-cara penyembuhannya, sehingga apabila salah satu pihak merasa tidak sesuai dengan apa yang diketahuinya atau tidak puas terhadap pelaksanaan perjanjian tersebut maka masing-masing pihak mempunyai hak untuk membatalkan perjanjiansesuai didalam Pasal 4 dan 12 undang-undang nomor 36 tahun 2009 tentang Kesehatan.

Hubungan hukum antara pasien dengan dokter dapat terjadi antara lain karena pasien sendiri yang mendatangi dokter untuk meminta pertolongan mengobati sakit yang dideritanya, dalam keadaan seperti ini terjadi persetujuan kehendak antara kedua belah pihak, dan terjadi hubungan hokum yang bersumber dari kepercayaan pasien terhadap dokter, sehingga pasien bersedia memberikan persetujuan. Kepatuhan pasien terhadap proses pengobatan dan nasihat yang Diberikan oleh dokter akan tercapai bila dokter dapat mengadakan komunikasi timbal balik yang baik terhadap pasiennya. 
sien,akan menyebabkan pasien lebih bersedia mematuhi proses upaya penyembuhan sehingga tujuan perjanjian yaitu kesembuhan dapat tercapai.

Kerjasama antara dokter dan pasien sangat diperlukan demi tercapainya pelayanan kesehatan yang memadai. Pelayanan kesehatan merupakan setiap upaya yang diselenggarakan secara mandiri atau bersama-sama dalam suatu organisasi untuk meningkatkan dan Memelihara kesehatan, mencegah dan menyembuhkan penyakit serta memulihkan kesehatan perorangan,keluarga, Kelompok dan atau pun masyarakat.

Mutu pelayanan kesehatan berkaitan dengan mutu dan tingkat kepuasan pasien sebagai konsumen. Jaminan atas pelayanan kesehatan yang bermutu adalah suatu proses pemenuhan standar mutu pengelolaan pelayaan kesehatan secara konsistendan berkelanjutan sehingga konsumen memperoleh kepuasan.

Keyataannya Yayasan Pemberdayaan Konsumen Kesehatan Indonesia (YPKKI) mencatat 60 hingga 65 persen kasus malapraktik bersumber dari dokter. Pernyataan Ketua YPKKI, Dr Marius Widjajarta tersebut menjadi salah satu dasar Yayasan Lembaga Konsumen Indonesia (YLKI) Sulsel tentang praktek kedokteran atau kedokteran gigi dalam perlindungan konsumen, Sementara Koordinator Umum YLKI Sulsel, Ambo Masse, di Makassar, Minggu (2/8), mengungkapkan dalam presentasinya pada seminar hukum kesehatan praktik dokter gigi dan dokter gigi spesialis berdasarkan kompetensi ditinjau perspektif hukum, masih banyak masyarakat beranggapan, malpraktik yang dialaminya adalah takdir. Bahkan tidak mengetahui kalau malpraktik bisa dilaporkan. Dewan Penasehat Ikatan Dokter Indonesia, Prof Hasbullah Thabrany mengatakan, dari seratus kejadian malpraktik mungkin cuma sepuluh yang dilaporkan. Salah satu penyebabnya adalah catatan medik di rumah atau tempat praktek tidak lengkap. Akibatnya, sulit untuk melacak prosedur penanganan yang dilakukan dokter.

Banyaknya masalah malapraktik di atas karena pada saat ini Undang-Undang No 29 tahun 2004 tentang Praktik Kedokteran belum dapat terealisasi dengan baik, dimana undang-undang ini diharapkan dapat mengatur praktik kedokteran dengan tujuan agar dapat memberikan perlindungan kepada pasien, mempertahankan dan meningkatkan mutu pelayanan medis dan memberikan kepastian hukum kepada masyarakat, dokter dan dokter gigi.Undang-undang No 29 tahun 2004 tentang Praktik Kedokteran 
merupakan dasar sehingga perjanjian terapeutik antara dokter dan pasien memiliki hubungan transaksi yang diakui secara hukum dan medis. Undang- undang ini juga mengatur tentang persyaratan dokter untuk dapat berpraktik kedokteran, yang dimulai dengan keharusan memiliki sertifikat kompetensi kedokteran yang diperoleh dari Kolegium selain ijasah dokter yang telah dimilikinya, keharusan memperoleh Surat Tanda Registrasi (STR) dari Konsil Kedokteran Indonesia dan kemudian memperoleh Surat ijin Praktik (SIP) dari Dinas Kesehatan Kota / Kabupaten. Dokter tersebut juga harus telah mengucapkan sumpah dokter, sehat fisik dan mental serta menyatakan akan mematuhi dan melaksanakan ketentuan etika profesi.

Pada bagian ini Undang-Undang juga mengatur tentang hak dan kewajiban dokter dan pasien. Salah satu hak dokter yang penting adalah memperoleh perlindungan hukum sepanjang melaksanakan tugas sesuai dengan standarprofesi dan standar prosedur operasional, sedangkan hak pasien yang terpenting adalah hak memperoleh penjelasan tentang penyakit, tindakan medis, manfaat, risiko, komplikasi dan prognosisnya dan serta hak untuk menyetujui atau menolak tindakan medis.

Pada bagian berikutnya Undang-Undang No 29/2004 mengatur tentang disiplin profesi. Undang-Undang mendirikan Majelis Kehormatan Disiplin Kedokteran Indonesia (MKDKI) yang bertugas menerima pengaduan, memeriksa dan memutuskan kasus pelanggaran disiplin dokter. Sanksi yang diberikan oleh MKDKI adalah berupa peringatan tertulis, rekomendasi pencabutan Surat Tanda Registrasi (STR) ,Surat Izin Praktek (SIP) dokter/dokter gigi, dan kewajiban mengikuti pendidikan dan pelatihan tertentu.Dalam melakukan pelayanan medis atau tindakan kedokteran yang telah disepakati kadang terjadi kesalahan dan kelalaian yang mengakibatkan malpraktik terjadi.Hasil dari perlakuan salah yang dilakukan oleh dokter dalam hubungannya dengan upaya penyembuhan yang telah diperjanjikan didalam kontrak terapeutik inilah yang mengakibatkan kerugian perdata.

\section{Tinjauan Pustaka}

\section{Perjanjian Terapeutik}

Terapeutik dapat diartikan sebagai hubungan hukum antara dokter dan pasien 
dalam pelayanan medis secara profesional didasarkan pada kompetensi yang sesuai dengan keahlian danketerampilan tertentu di bidang kesehatan .

Menurut Hermien Hadiati Koewadji Terapeutik adalah terjemahan dari therapeutic yang berarti dalam bidang pengobatan, ini tidak sama dengan therapy atau terapi yang berarti pengobatan ${ }^{3}$.

Salim, H.S mengatakan persetujuan yang terjadi antara dokter dan pasien bukan hanya dibidang pengobatan tetapi juga mencakup bidang diagnostik, preventif, rehabilitatif dan promotif, persetujuan ini disebut perjanjian terapeutik atau transaksi terapeutik ${ }^{4}$

Perjanjian Terapeutik disamakan dengan bentuk inspaningsverbitenis karena dalam perjanjian ini dokter hanya berusaha untuk menyembuhkan pasien dan upaya yang dilakukan belum tentu berhasil. Hubungan dokter dan pasien dalam transaksi terapeutik (perjanjian medis) bertumpu pada dua macam hak asasi yang merupakan hak dasar manusia yaitu:

1. Hak untuk menentukan nasib sendiri (the right toself determinations)

2. Hak atas dasar informasi (the right to information $)^{5}$

Hak menentukan nasib sendiri merupakan hak manusiayang telah ditentukan oleh Tuhan Yang Maha Esa atas diri seseorang. Hak atas dasar informasi merupakan hak untuk memperoleh keterangan yang berhubungan dengan kesehatan. Para pihak yang terlibat dalam perjanjian/kontrak medis ini adalah dokter dan pasien

Dalam pengertiannya tersebut perjanjian terapeutik dapat ditarik beberapa unsur, yaitu:

a. Adanya Subjek perjanjian, meliputi pasien dan tenaga kesehatan/dokter/dokter gigi

3 HermienHadiatiKoeswadji.MakalahSimposiumHukumKedokteran(Medical Law).Jakarta: BadanPembinaanHukumNasionHermien Hadiati Koeswadji al.Hlm. 142

4 SalimHS. 2006.PerkembanganHukumKontrak diLuarKUHPerdata,Rajawali Press, Jakarta.,Hlm.45

5 Hermien Hadiati Koeswadji. Op.cit. Hlm 143 
b. Adanya objek perjanjian, yaitu upaya maksimal untuk melakukan penyembuhan terhadap pasien

c. Kewajiban pasien,membaya biaya penyembuhan

Dalam pelaksanaanya perjanjian terapeutik ini harus didahului oleh adanya persetujuan tindakan tenaga kesehatan/dokter/dokter gigi terhadap pasien yang disebut Informend consent. Istilah transaksi atau perjanjian terapeutik memang tidak dikenal dalam KUH Perdata, akan tetapi unsur yang terkandung dalam perjanjian terapeutik dapat dikategorikan sebagai suatu perjanjian sebagaimana diterangkan dalam Pasal 1319 KUH Perdata yang menyatakan bahwa:

"Semua persetujuan, baik yang mempunyai nama khusus , maupun yang tidak dikenak dalam suatu nama tertentu, tunduk pada peraturan umum yang termuat dalam bab ini dan bab yang lalu"

Perjanjian Terapeutik adalah perikatan yang dilakukan antara dokter dengan pasien, berupa hubungan hukum yang melahirkan hak dan kewajiban bagi kedua belah pihak. Berbeda dengan perjanjian pada umumnya, perjanjian terapeutik memiliki sifat dan ciriciri khusus sebagaimana dimuat dalam deklarasi Helsinki yang penyusunannya berpedoman pada The Nuremberg Code yang semula disebut persetujuan sukarela , dikemukakan mengenai 4 (empat) syarat sahnya persetujuan yang harus diberikan secara sukarela, yaitu: 6

1. Persetujuan harus diberikan secara sukarela

2. Diberikan oleh yang berwenang dalam hukum

3. Diberitahukan

4. Dipahami.

Persetujuan dalam praktek kedokteran sangat dibutuhkan untuk melindungi kepentingan pasien. Pada saat pasien melakukan konsultasi, keempat hal persetujuan 
tersebut diperlukan karena bentuk persetujuan pasien hanya dalam bentuk lisan sehingga kesepakatan yang terjadi merupakan kesepakatan yang lahir secara abstrak , dan pada saat dokter melakukan terapi maka persetujuan pasien tersebut beruba menjadi suatu perjanjian yang konkrit.

\section{Akibat Hukum Perjajian Terapeutik}

Menurut Hasanudin RahmanPemenuhan hak dan kewajiban merupakan suatu suatu bentuk akibat dari suatu perjanjian. Hak dan kewajiban inilah yang kemudian menimbulkan hubungan timbal balik antara para pihak, yaitu kewajiban pada pihak pertamamerupakan hak bagi pihak kedua, begitu pula sebaliknya kewajiban dari pihak kedua merupakan hak bagi pihak pertama7.

Para pihak dalam perjanjian saling mengikatkan dirinya untuk melaksanakan suatu maksud dan tujuan. Dengan adanya tanggung-jawab terhadap apa yang diperjanjikan maka para pihak diharapkan seteliti mungkin dalam melaksanakan dan membuat suatu perjajian sehingga tidak saling merugikan, sesuai dengan Pasal $1339 \mathrm{KUH}$ Perdata yaitu;

"Persetujuan tidak hanya mengikat apa yang dengan tegas mengikat didalamnya, melainkan juga segala sesuatu yang menrut sifat persetujuan dituntut berdasarkan keadilan, kebiasaan, atau undang-undang."

\section{Para pihak dalam perjanjian terapeutik}

Dalam perjanjian terapeutik disebutkan bahwa objek perjanjian terapeutik adalah pelayanan medis atau upaya penyembuhan. Berdasarkan Permenkes RI No. 585/Men.Kes/pPer/ IX/1989 bahwa pelayanan medis/tindakan medis adalah tindakan yang dilakukan terhadap pasien yang berupa tindakan diagnostic atau terapeutik. Dari batasan itu dapat dipahami bahwa:

a. Tindakan medis yang berupa diagnosa dan terapeutik itu adalah tindakan yang

\footnotetext{
${ }^{7}$ Hasanudin Rahman. 2000.LegalDrafting.PTCitraadityaBakti.Bandung.Hlm.7
} 
hanya dapat dilakukan oleh tenaga medis dalam hal ini meliputi dokter, bidan dan perawat.

b. Tindakan itu dilakukan terhadap pasien

Dari penjelasan diatas disimpulkan bahwa tindakan medis dapat dilakukan sesuai dengan kompetensi dokter, bidan, dan perawat dimana pasien merupakan seseorang subjek yang ditindak sesuai peraturan tindakan medis tersebut, berikut penjelasan mengenai tenaga medis yaitu:

Dokter

Dokter, merupakan salah satu tenaga medis yang dapat diambil sebagai pihak yang melakukan atau melaksanakan pelayanan kesehatan. Pengertian dokter dapat dillihat pada ketentuan Pasal 1 angka 2 Undang-Undang Nomor 29 Tahun 2004 tentang Praktek Kedokteran, yaitu:

“ Dokter dan Dokter gigi adalah dokter, dokter spesialis, dokter gigi, dan dan dokter gigi spesialis lulusan pendidikan kedokteran atau kedokteran gigi baik di dalam maupun diluar negeri yang diakui oleh Pemerintah Republik Indonesia sesuai denga peraturan perundangundangan".

Dari penjelasan diatas maka dokter merupakan sebagai pengemban profesi yang mengabdikan diri dalam bidang kesehatan serta memiliki pengetahuan dan keterampilan melalui pendidikan dibidang kesehatan yang melakukan upaya kesehatan

Pasien

Soerjono Soekanto mengemukakan bahwa Pasien adalah orang sakit yang dirawat oleh dokter dan tenaga kesehatan lainnya ditempat praktek atau rumah sakit ${ }^{8}$. Pasien adalah orang yang menjadi sasaran dalam usaha-usaha penyembuhan yang dilakukan oleh dokter atau tenaga kesehatan lainya . Sebagai subjek hukum pasien mempunyai hak 
dan kewajiban yang harus dipahami baik oleh pasien, dokter maupun rumah sakit sebagai salah satu tempat diselenggarakanya profesi kedokteran demi tercapainya tujuan upaya kesehatan sesuai dengan ketentuan Undang-Undang No. 44 Tahun 2009 Pasal 1 angka 1 Tentang Rumah Sakit yaitu:

"Pasien adalah setiap orang yang melakukan konsultasi masalah kesehatannya untuk memperoleh pelayanan kesehatan yang diperlukan baik secara lansungmaupun tidak lansung di rumah sakit".

Rumah Sakit

Rumah Sakit, dapat diartikan sebagai sarana pelayanan kesehatan. Selain itu , rumah sakit juga dapat merupakan suatu tempat bagi tenaga medis berkumpul atau lokasi dimana berbagai tenaga ahli atau padat karya dan juga merupakan lembaga padat moral, padat teknologi dan padat waktu. Rumah sakit merupakan pusat pelayanan medis atau juga pelayanan kesehatan, sebagaimana sesuai dengan Undang-Undang Rumah Sakit No. 44 tahun 2009 Pasal 1 angka 1 yaitu:

"Rumah Sakit adalah institusi pelayanan kesehatan yang menyelenggarakan pelayanan kesehatan perorangan secara paripurna yang menyediakan pelayanan rawat inap, rawat jalan,dangawat darurat".

Rumah sakit merupakan pusat pelayanan medis atau juga pelayanan kesehatan, sebagaimana menurut A. Azwar untuk terselanggaranya pelayanan medis yang baik, banyak syarat yang harus dipenuhi, mencakup 8 (delapan) hal pokok yaitu tersedia (available), wajar (appropriate),berkesinambungan (continue), dapat diterima (acceptable), dapat dicapai (accesible), dapat dijangkau (affordable), efisien (effecient), dan bermutu (quality). ${ }^{9}$

Pelayanan kesehatan merupakan salah satu upaya yang dapat dilakukan untuk meningkatkan derajat kesehatan baik perseorangan, maupun kelompok atatu

\footnotetext{
${ }^{9}$ A.Azwar. 1994.StandarPelayananMedisMateri PenerapanStandarPelayanan RumahSakit,MedisdanPengawasanEtik. UjungPandang. Hlm.1
} 
masyarakat secara keseluruhan. Pelayanan medis merupakan suatu bentuk upaya yang diberikan oleh tenaga medis dokter/dokter gigi dan perawat sesuai yang diatur dalam Pasal 1 angka 1 Undang-undang Kesehatan No. 36 Tahun 2009 yaitu :

“Upaya Kesehatan adalah setiap kegiatan dan atauu serangkaian kegiatan yang dilakukan secara terpadu, terintegrasi dan berkesinambungan untuk memelihara dan meningkatkan derajat kesehatan masyarakat dalam bentuk pencegahan penyakit, peningkatan kesehatan, pengobatan penyakit, dan pemulihan kesehatan oleh pemerintah dan atau masyarakat"

\section{Pengertian Informend Consent}

Persetujuan tindakan medik adalah terjemahan yang dipakai untuk istilah informed consent. Informed dapat diartikan telah diberitahukan, telah disampaikan atau telah diinformasikan. Sedangkan consent adalah persetujuan yang diberikan kepada seseorang untuk berbuat sesuatu. Dengan demikian informed consent adalah persetujuan yang diberikan oleh pasien kepada dokter setelah diberi penjelasan.

Hal ini sesuai dengan pengertian informed consent dalam Permenkes No. 290/Menkes/Per/III/2008 dan Undang-Undang No. 29 Tahun 1945 serta Manual Persetujuan Tindakan Kedokteran KKI tahun 2008, yaitu Informed consent adalah persetujuan tindakan kedokteran yang diberikan oleh pasien atau keluarga terdekatnya setelah mendapatkan penjelasan secara lengkap mengenai tindakan kedokteran yang akan dilakukan kepada pasien tersebut.

"Jusuf Hanafiah mengemukakan bahwa maksud dari informed atau memberi penjelasan adalah semua keadaan yang berhubungan dengan penyakit pasien dan tindakan apa yang akan dilakukan dokter serta hal-hal yang perlu dijelaskan dokter kepada pasien dan keluarga "10.

10 Jusuf Hanafiah dan Ari Amir. 1999. Etika kedokteran dan hukum

kesehatan. EGC. Jakarta.Hlm 68 
Informasi yang diberikan adalah informasi yang selengkaplengkapnya yaitu informasi yang akurat tentang perlunya tindakan medis yang bersangkutan dan informasi tentang risiko yang dapat ditimbulkan.

\section{Bentuk Informed Consent}

Informed consent merupakan dasar dokter dalam melakukan penanganan medik terhadap pasien. Dalam sebuah informed consent terdapat persetujuan yang harus ada, yang didalamnya memuat tentang persetujuan pasien terhadap tindakan medik yang akan dilakukan dokter terhadap dirinya. Sedangkan dilihat dari bentuknya, ada dua bentuk persetujuan tindakan medik atau informed consent yaitu:

\section{Tersirat atau dianggap telah diberikan (Implied Consent)}

"Implied consent" adalah persetujuan yang diberikan pasien secara tersirat, tanpa pernyataan tegas. Isyarat persetujuan ini ditangkap oleh dokter dari sikap dan tindakan pasien. Umumnya tindakan dokter yang biasa dilakukan atau sudah diketahui umum.

Implied consent bentuk lain adalah bila pasien dalam keadaan gawat darurat (emergency) sedang dokter memerlukan tindakan segera, sementara pasien dalam keadaan tidak bisa memberikan persetujuan dan keluarga yang tidak berada ditempat, maka dokter dapat melakukan tindakan medik ini sesuai dengan

Kepmenkes 290 Tahun 2008 Mengenai Pesetujuan Tindakan Kedokteran Pasal 4 angka 1 yang mengatur bahwa:

“ Dalam keadaan darurat, untuk menyelamatkan jiwa pasien dan atau mencegah kecacatan tidak diperlukan persetujuan tindakan kedokteran"

\section{Express Consent (dinyatakan)}

"Expressed consent" adalah persetujuan yang dinyatakan secara lisan atau tertulis bila yang akan dilakukan lebih dari prosedur pemeriksaan dan tindakan biasa". ${ }^{11}$ Ini sesuai

11 Ibid.hlm. 70. 
dengan Kepmenkes 290 Tahun 2008 Pesetujuan Tindakan Kedokteran Pasal 3 Ayat(1) yang mengatur bahwa:

"Setiap tindakan dokter yang mengandung resiko tinggi harus memperoleh persetujuan tertulis yang ditandatangani oleh yang berhak memberikan persetujuan."

Dalam expressed consent persetujuan harus ada, persetujuan dimana didalamnya terdapat informasi sebelum dilakukan penanganan medis . bentuk dari persetujuan expressed consent dapat berupa:

Dokter dalam melakukan penanganan medik hanya memerlukan pernyataan lisan saja dalam hal ini terhdap tindakan yang tidak invasif (tidak mengandung risiko yang besar). Segi praktis dan kelancaran penanganan medis yang dilakukan dokter merupakan alasan dari penyampaian persetujuan secara lisan. Dokter dituntut untuk membiasakan diri untuk menulis atau mencatat persetujuan lisan pasien itu pada rekam medis atau rekam kesehatan, karena segala kegiatan yang dilakukan oleh dokter harus dicatat dalam rekam medis termasuk persetujuan pasien secara lisan.

Dokter dalam melakukan penanganan medik harus mendapat persetujuan secara tertulis dari pihak pasien. Persetujuan dilakukan secara tertulis dilakukan terhadap penanganan medik yang mengandung risiko seperti tindakan pembedahan atau prosedur pemeriksaan dan pengobatan invasif (mengandung risiko yang besar). Persetujuan tersebut dalam bentuk formulir-formulir persetujuan bedah, operasi dan lain-lain yang harus diisi (umummnya). Dari segi hukum positif, formulir persetujuan ini sangat penting sebagai bukti tertulis yang dikemukakan oleh para pihak kepada hakim bila terjadi kasus malapraktek. Oleh karena itu, pengisian data pada formulir itu harus tepat dan benar sehingga tidak menjadi masalah dikemudian hari.

Dalam Pelaksanaan perjanjian medis antara tenaga kesehatan (dokter, bidan, perawat) dengan pasien dahulu merupakan hubungan yang tidak seimbang, karena pasien sebagai pihak yang meminta pertolongan benar-benar pasrah kepada tenaga medis (dokter, bidan, perawat) yang memberi perawatan. Berdasarkan kemajuan masyarakat dan ilmu pengetahuan di bidang kesehatan, hubungan yang bersifat tidak seimbang ini secara perlahan-lahan mengalami perubahan. Menurut Soerjono Soekanto 
Perubahan itu terjadi karena:

1. Kepercayaan tidak lagi pada dokter secara pribadi, akan tetapi kepada ilmu kedokteran;

2. Adanya kecendrungan untuk menyatakan bahwa kesehatan itu bukan lagi merupakan keadaaan tanpa penyakit, akan tetapi berarti kesejahteraan fisik, mental dan sosial;

3. Semakin banyaknya peraturan yang memberikan perlindungan hukum kepada pasien $^{12}$

\section{METODE PENELITIAN}

\section{A. LokasiPenelitian}

Penelitianini dilaksanakan di Makassar. Dari sejumlah rumah sakit yang ada di kota Makassar, maka penulis hanya akan memilih dua rumah sakit yaitu rumah sakit pemerintah Wahidin Sudirohusodo dan rumah sakit swasta Grestelina

Dasar pertimbangan penulis karena pada rumah sakit tersebut banyak terdapat hubungan antara dokter dan pasien yang berkaitan langsung dengan perjanjian terapeutik di banding daerah lain, karenaitupenelitimencobamenelitimasalahhukum yang ada di lokasi penelitian berkenaan dengan Perjanjian Terapeutik Sebagai Dasar Bagi Dokter Dalam melakukan Penanganan Medis.

\section{B. Jenis dan Sumber Data}

Jenis data adalah data perimer dan data sekunder.

Data primer diperoleh dari pada responden kalangan dokter dan kalangan pasien dan atau keluarganyayaitu data yang diperolehdarihasilwawancaralangsung, serta hasil pengamatan langsung yaitu penangan medis yang dilakukan oleh dokterkepada pasien 
ditempat penelitian

1. Data Sekunder merupakan data yang sah berasal dari rumah sakit yaitu :

a. Jumlah dokter yang melakukan praktek di rumah sakit(keseluruan spesialis dan umum)

b. Contoh dan isi rekam medis (cukup keterangan mengenai isi rekam medis dan penjelasannya)

c. Bahan bacaan baik dalam bentuk literatur serta karya ilmiah yang berkaitan dengan penelitiandan rumusan masalah yang diangkat.

\section{TeknikPengumpulan Data}

Teknik pengumpulan datadilakukan sebagai berikut:

1. Studi lapangan, dengan cara peneliti langsung mendatangi tempat penelitian dan melakukan langkah-langkah

a. Wawancara langsung dengan responden Data ini didapatkan melalui Hasil wawancara yang diambil dari 10 koresponden pasien dan 10 Koresponden dokter/dokter gigi Rumah Sakit Dokter Wahidin Sudirohusodo dan rumah sakit Grestlina yang terbagi dokter bedah, endokrin, umum dan ppds (program pendidikan dokter spesialis)

2. Studi Pustaka, dalam hal ini peneliti aktif mengidentifikasi data sekunder dalam berbagai bahan bacaan:

a. Karya ilmiah dalam bentuk skripsi,makalah, dan majalah

b. Peraturan perundang-undangan dan dokumentasi

c. Buku literatur.

\section{Analisis Data}

Data primer dan data sekunder yang telah terkumpul, kemudian diolah dan dianalisis. Data dideskripsikan secara kualitatif yaitu dengan menggambarkan apa yang telah dinyatakan oleh responden Secara lisan atau tertulis maupun perilaku yang nyata, kemudian pada akhirnya ditarik suatu kesimpulan yang meliputi keseluruhan hasil 
pembahasan atau analisa data yang telah dilakukan.

Pembahasan

\section{Informend Consent didalam Perjanjian Terapeutik}

Hubungan medis yang terjadi antara pasien dan dokter dimulai ketika seorang pasien mendatangi tempat dokter berpraktik pribadi ataupun rumah sakit, ini sesuai dengan penjelasan Undang-undang No. 44 tahun 2009 Pasal 1 Angka 4 Tentang Rumah Sakit disebutkan bahwa:

"Pasien adalah setiap orang yang melakukan konsultasi masalah kesehatannya untuk memperoleh pelayanan kesehatan yang diperlukan, baik secara langsung maupun tidak langsung di Rumah Sakit".

Dokter yang memiliki STR (Surat Tanda Registrasi) dan SIP (Surat Izin Praktik ) dianggap berhak melakukan pemeriksaan terhadap diri pasien.Fungsi dari kelengkapan izin tersebut untuk menjamin kualitas dan keprofesionalan dokter serta yang terpenting adalah menjamin kepastian hukum dalam penanganan medis yang dilakukan oleh seorang dokter, hal ini sesuai dengan undang-undang No. 29 tahun 2004tentang Praktik kedokteran Pasal 3 Point C dimana salah satu tujuan dari pengaturan sertifikasi praktik kedokteran adalah memberikan kepastian hukum kepada masyarakat dan dokter/dokter gigi.

Pasien yang datang kepada dokter dalam keadaan tidak sadar merupakan pasien yang digolongkansebagai pasien yang memerlukan bantuan segera atau disebut sebagai suatu keadaan darurat, dimana dalam keadaan ini tidak diperlukannya penjelasan oleh dokter karena keadaan pasien yang membutuhkan pertolongan untuk mencegah kecacatan ataupun penyelamatan nyawa pasien, ini diatur dalam undang-undang No. 44 tahun 2009 Pasal 1 angka 2 tentang rumah sakit.

Penanganan medis yang dilakukan oleh dokter merupakan bagian dari perjanjian terapeutik dimana penjelasan mengenai tindakan medis dokter yang disebut dengan Informenddiberikan kepada pasien. Pasien merupakan seseorang yang mengambil keputusan berdasarkan Informend yang diberikan oleh seorang dokter, bagi pasien dalam keadaan tidak sadar maka informend diberikan setelah sadar atau diberikan 
kepada keluarga pasien yang sah dan berhak secara hukum.

Hasil dari keputusan untuk melakukan perawatan medis inilah yang disebut dengan Consent atau persetujuan pasien tehadap perawatan atau penaganan medis yang akan dilakukan oleh dokter.Informend consent ini melahirkan perikatan sesuai dengan KUH Perdata Pasal 1233 dan Pasal 1320 mengenai syarat-syarat terjadinya persetujuan yang sah.

Didalam transaksi terapeutik, penerima palayanan medis terdiri dari pasien orang dewasa yang cakap untuk bertindak, orang dewasa yangbelum dinyatakan cakap sehingga memerlukan persetujuan dari pengampunya dan anak dibawah umur yang memerlukan persetujuan dari orang tuanya. Untuk hal tertentu suatu upaya penyembuhan yang dalam pelaksanaannya memerlukan kerjasama yang berdasarkan sikap saling percaya. Sedangkan yang dimaksud oleh sebab yang halal adalah sesuatu yang tidak dilarang oleh Undang- Undang serta tidak bertentangan dengan kesusilaan dan ketertiban umum. Informed consent harus tetap diberikan walaupun pada pemeriksaan dipoliklinik rawat jalan, karena persetujuan medis akan timbul setelah pasien diberi penjelasan mengenai penyakitnya dan akibat-akibatnya yang dapat diperhitungkan menurut ilmu kedokteran dan kemudian pasien menyetujuinya.

Suatu Informend Consent baru sah diberikan oleh pasien jika memenuhi minimal 3 (tiga) unsur sebagai berikut:

a) Keterbukaan informasi yang cukup diberikan oleh dokter ini sesuai dengan Kepmenkes290/MENKES/PER/III/2008 Pasal 1 Angka 1 yang menyebutkan bahwa Persetujuan pasien atau keluarganya diberikan kepada pasien setelah adanya penjelasan secara lengkap mengenai tindakan kedokteran yang akan dilaksanakan

b) Kompetensi pasien dalam memberikan persetujuan sangat penting agar dapat membuat keputusan secara sadar ini sesuai diterangkan dalam dengan Kepmenkes 290/MENKES/PER/III/2008 Pasal 1 Angka 7 mengenai informend consent

c) Kesukarelaan (tanpa paksan atau tekanan) dalam memberikan persetujuan. 
Informasi/penjelasan yang diatur didalam aturan Kepmenkes 290 /MENKES /PER/III/2008 tentang "Persetujuan Tindakan Medik atau Informed Consent, bahwa setiap tindakan medis dan pengobatan, pasien harus diberi penjelasan kemudian menandatangani blangko/formulir persetujuan tindakan medis yang telah disediakan oleh Rumah Sakit.

Dokter merupakan profesi yang mulia dalam presepsi masyarakat karena menurut pandangan penulis dokter tidak hanya memiliki kewajiban menolong pasien di lingkungan rumah sakit atau praktek pribadi tetapi dokter juga harus memiliki inisiatif ketika terjadi suatu keadaan yang memerlukan bantuan dokter secara cepat contohnya:

1) Kecelakaan lalu lintas yang memerlukan tindakan dan bantuan dokter segera.

2) Kewajiban sosial dalam membantu korban bencana alam.

3) Memberikan penyuluhan mengenai pentingnya kesehatan seperti bahaya merokok dan penjelasan mengenai indikasi suatu obat

Hubungan antara dokter dan paien saat ini cukup baik dilihat dari grafik responden diatas yang memperlihatkan keseimbangan antara hak dan kewajiban yang dilakukan oleh dokter dan pasien. Dokter harus menyadari bahwa "informedconsent" benarbenar dapat menjamin terlaksananya hubungan hukum antara pihak pasiendengan dokter, atas dasar saling memenuhi hak dan kewajiban masing-masing pihak yangseimbang dan dapat dipertanggungjawabkan. Masih banyak hal dari informed consent ini sifatnya relative, misalnya tidak mudah untuk menentukan apakah suatu inforamsi sudah ataubelum cukup diberikan oleh dokter.

\section{B. Pengaturan Hak dan Kewajiban Dokter dalamPerjanjian Terapeutik}

Dalam hubungan hukum, dokter dan pasien bertindak sebagai "subjek hukum " yakni orang yang mempunyai hak dan kewajiban, sedangkan pasien sebagai "objek hukum" yakni sesuatu yang bernilai dan bermanfaat bagi orang sebagai subyek hukum, dan akan terjadi perbuatan hukum yaitu jasa tindakan medis, disamping terikat oleh KODEKI (Kode Etik Kedokteran Indonesia) bagi dokter, juga tetap tidak dapat melepaskan diri dari ketentuan-ketentuan hukun perdata, hukum pidana maupun 
hukum administrasi, sepanjang hal itu dapat diterapkan.

Aspek Hukum Perdata, suatu tindakan medis yang dilakukan oleh dokter tanpa adanya persetujuan dari pihak pasien, sedangkan pasien dalam keadaan sadar penuh dan mampu memberikan persetujuan, maka dokter sebagai pelaksana tindakan medis dapat dipersalahkan dan digugat telah melakukan suatu perbuatan melanggar hukum (onrechtmatige daad) berdasarkan Pasal 1365 Kitab Undang-undang Hukum Perdata (KUHPer). Hal ini karena pasien mempunyai hak atas tubuhnya, sehingga dokter harus menghormatinya.

Aspek Hukum Pidana, "informed consent" mutlak harus dipenuhi dengan adanya Pasal 351 Kitab Undang-Undang Hukum Pidana (KUHP) tentang penganiayaan. Suatu tindakan invasive (misalnya pembedahan, tindakan radiology invasive) yang dilakukan dokter tanpa adanya izin dari pihak pasien, maka dokter dapat dituntut telah melakukan tindak pidana penganiayaan yaitu telah melakukan pelanggaran terhadap Pasal 351 KUHP

Kehormatan profesi kedokteran terletak pada kepercayaan pasien terhadap profesi dokter, maka kedudukan yang lemah pada pasien tidak boleh disalahgunakan. Agar mendapatkan kepercayaan dari pasien, dokter harus berpegang pada standar etis yaitu KODEKI melalui Surat

Keputusan Pengurus Besar Ikatan Dokter Indonesia N0.221/PB/A.4/04/2002 tentang penerapan kode etik kedokteran Indonesia yang berfungsi sebagai pedoman bagi dokter dalam melakukan penanganan medis dan menjadi dasar bagi pengetahuan dan ketrampilan profesi yang dimilikinya, dengan asas-asasnya primum non nocere yang artinya sejak dari awal tidak ada niat untuk menyakiti, mencederai, merugikan atau mencelakakan pasien, baik secara langsung maupun secara tidak langsung.

Tindakan medis seorang dokter juga harus bersifat beneficence artinya segala tindakan medis yang dilakukan itu untuk kebaikan sosial , agama, jenis kelamin, politik, dan jujur, yakni dokter menghargai hak pasien, memahami batas kompetensinya ini sesuai dalam KODEKI (Kode etik Kedokteran Indonesia) Pasal 10 sampai dengan Pasal 14. Pelayanan kesehatan dalam pelaksanaan dokter haruslah didasarkan pada 
penghargaan atas martabat manusia dan upaya pelayanan yang

menjunjung tinggi nilai-nilai kemanusiaan seutuhnya. Oleh karena itu, Ikatan Dokter Indonesia (IDI) sebagai satu-satunnya organisasi profesi para dokter di Indonesia, terbentuk agar dapat memberikan pelayanan kedokteran yang bermutu dan profesional, yang menjunjung tinggi etika kedokteran serta peningkatan kemampuan mengembangkan ilmu pengetahuan dan teknologi kedokteran, pemberdayaan dan kebebasan

\section{Profesi kedokteran.}

Fungsi kode etik profesi antara lain sebagai alat kontrol sosial.Kode etik memberikan suatu kriteria bagi para calon anggota kelompok profesi dan membantu mempertahankan pandangan para anggota lama terhadap prinsip profesional yang telah digariskan. Kode etik profesi juga berfungsi untuk mencegah pengawasan ataupun campur tangan yang dilakukan pemerintah atau masyarakat. Selain itu, kode etik profesi penting untuk pengembangan patokan kehendak yang lebih tinggi. Karena pada dasarnya, melalui kode etik pelaku profesi dianggap sebagai prilaku yang sudah benar serta berdasarkan metode prosedur yang benar pula.

Pelayanan medis, seorang dokter dapat dilihat dalam kedudukannya selaku profesional di bidang medik yang senantiasa harus berperan aktif, dan pasien dapat dilihat dalam kedudukannya sebagai penerimapelayananmedik yang mempunyai penilaian terhadap penampilan dan mutu pelayanan medik yang diterimanya. Hal ini disebabkan, dokter bukan hanya melaksanakan pekerjaan melayani atau memberi pertolongan serta melaksanakan pekerjaan profesi yang terikat pada suatu kode etik.

Profesi dapat pula diartikan sebagi suatu pekerjaan yang memerlukanpendidikan dan pelatihan tertentu, dalamjenjang kehidupan bermasyarakat profesi mendapat kedudukan yang tinggi dalam masyarakat, seperti dapat dicontohkan hakim, pengacara, notaris, ataupun dokter. Berbeda dengan profesi pada umumnya,profesi kedokteran merupakan profesi yang dianggap paling mulia karena berhadapan langsung dengan masalah kesehatan dan kehidupan. Oleh karena itu, profesi medis hakikatnya adalah merupakan panggilan jiwa, yaitu panggilan untuk mengabdikan diri pada kemanusiaan, 
berlandaskan atas akhlak dan moral yang luhur. Karenanya dibutuhkan suatu standar atau batasan kemampuan minimal (knowledge, skill, dan attitude) yang harus dikuasai oleh seorang dokter

Perkembangan ilmu pengetahuan dan teknologi profesidokter terintegrasi di dalam rumah sakit untuk memberikan pelayanan medis. Upaya pelayanan medis yang dilakukan oleh dokter di rumah sakit pada prinsipnya karena adanya suatu hubungan kerja. Dengan adannya hubungan perjanjian kerja, tenaga kesehatan menjadi staf dari rumah sakit. Namun, demikian, dengan semakin banyaknya spesialisasi dokter, maka tidaktertutup kemungkinan bagi yang bukan staf medis dari rumah sakit yang bersangkutan dapat melakukan pelayanan medis pada rumah sakit tersebut.

Pelayanan medis yang dilakukan oleh dokter pada pasien didasarkan pada suatu hubungan kepercayaan. Pasien percaya kapada dokter, bahwa dokter mempunyai pengetahuan dan pengalaman tentang pengobatan penyakit. Oleh karena itu, seorang dokter di dalam suatu upaya pelayanan medis mempunyai hak dan kewajiban untuk berinisiatif menentukan sendiri tindakan medis. Hak dan kewajiban dokter untuk menentukan sendiri tindakan medis tersebut didasarkan pada pertimbangan bahwa dokter mempunyai kemampuan dan keahlian di bidang kedokteran ini sesua dengan undang-undang No. 29 Tentang Praktik Kedokteran Pasal 1 Angka 11 yang mengatur bahwa:

"Profesi kedokteran atau kedokteran gigi adalah suatu pekerjaan kedokteran atau kedokteran gigi yang dilaksanakan berdasarkan suatu keilmuan, kompetensi yang diperoleh melalui pendidikan yang berjenjang, dan kode etik yang bersifat melayani masyarakat. " Dengan demikian dapat dikatakan bahwa hubungan antara dokter dan rumah sakit adalah suatu hubungan kerja di dalam pelayanan medis.

\section{Referensi:}

A.Azwar. Standar Pelayanan Medis Materi Penerapan Standar Pelayanan Rumah Sakit, Medis danPengawasan Etik. 1994; UjungPandang.

Hasanudin Rahman. Legal Drafting. PT. Citra Aditya Bakti. 2000; Bandung. 
Hermien Hadiati Koeswadji. Makalah Simposium Hukum Kedokteran (Medical Law). Jakarta: Badan Pembinaan Hukum Nasional Hermien Hadiati Koeswadji.

Jusuf Hanafiah dan Ari Amir.. Etika kedokteran dan hokum kesehatan. EGC. 1999; Jakarta.

SalimHS, Perkembangan Hukum Kontrak diLuar KUHPerdata, Rajawali Press, 2006; Jakarta.,

Soerjono Soekanto. Segi-segi Hukum Hak Dan Kewajiban Pasien (dalam Kerangka Hukum Kesehatan). Mandar Maju. 1990;Jakarta

SoerjonoSoekanto Kontrak Terapeutik Antara Pasiendengan Tenaga Medis.MediaHospital. 1987; Jakarta.

\section{Undang-Undang}

Undang-Undang Nomor 36 Tahun 2009 Tentang Kesehatan

Undang-Undang No. 44 Tahun 2009 Tentang Rumah Sakit

Undang-Undang Nomor 29 Tahun 2004 Tentang Praktik Kedokteran

Kitab Undang-undang Hukum Perdata (KUHPerdata) Burglijk Wetbook

Permenkes No. 290/Menkes/Per/III/2008

Permenkes RI No. 585/Men.Kes/pPer/ IX/1989

\section{Webpage:}

http://www.webcitation.org/query?url=http://www.geocities.com/travbaile y/Paul_Weindling_The_Origins_of_Informed_Consent_Nuremburg_Code.htm\&da te=. Waktu akses 2009-10-25+23: 15:42 